\title{
Studies on the recovery of uranium from nuclear industrial effluent using nanoporous silica adsorbent
}

\author{
H. Sepehrian $\cdot$ M. Samadfam $\cdot$ Z. Asadi
}

Received: 27 February 2011/Revised: 12 July 2011/Accepted: 19 November 2011/Published online: 20 April 2012

(c) CEERS, IAU 2012

\begin{abstract}
In this paper, the sorption of uranium onto nanoporous silica adsorbent in the presence of nitrate, sulfate, chloride, fluoride and phosphate was studied. The effect of contact time between the nanoporous sorbent and aqueous solution, $\mathrm{pH}$ and initial concentration of uranium was also investigated. Uranium sorption onto nanoporous silica adsorbent is a very fast process as sorption rate increases with $\mathrm{pH}$ increment. Optimum $\mathrm{pH}$ for uranium sorption was 4-8. Experimental sorption isotherm is successfully described by Langmuir and Freundlich models. The results obtained by batch experiments showed that the presence of high concentration of nitrate, sulfate, chloride and phosphate anions alone had no interference with uranium recovery. However, the presence of fluoride ions ( $>250 \mathrm{mg} / \mathrm{L})$ decreases uranium sorption by about $55 \%$. The results also showed that the presence of phosphate ions (about $300 \mathrm{mg} / \mathrm{L}$ ) in solution could remove fluoride interference completely. Finally, the efficiency of the nanoporous silica adsorbent for uranium recovery from wastewater of the uranium conversion facility was investigated.
\end{abstract}

H. Sepehrian $(\bowtie)$

Nuclear Science and Technology Research Institute,

AEOI, P.O. Box 11365/8486, Tehran, Iran

e-mail: hsepehrian@aeoi.org.ir

M. Samadfam · Z. Asadi

Department of Energy Engineering,

Sharif University of Technology,

Tehran, Iran
Keywords Anions interference - Langmuir and Freundlich models · Uranium adsorption

\section{Introduction}

The recovery of nuclear elements such as uranium from aqueous systems, especially from industrial effluents has recently become the centre of a wide interest in exploiting undeveloped energy sources and environmental control (Nakajima and Sakaguchi 1999). Recovery of uranium was reported over years by various methods like liquidliquid extraction (LLE), ion exchange, nano/ultra filtration, biosorption, coprecipitation, electrodeposition, solid phase extraction (SPE), imprinted polymers, liquid membranes, resin-in-pulp, solid state reaction, etc. (Michard et al. 1996; Tsuruta 2002; Kulkarni 2003; Chaudhury et al. 2003; Amamoto et al. 2005; Mirjalili and Roshani 2007; James et al. 2009; Akhtar et al. 2009; Singh et al. 2009).

In the industrial effluent, uranium is capable of forming anionic species mainly, uranyl carbonate, uranyl, fluoride, uranyl chloride, uranyl phosphate or uranyl sulfate. The strange base anion exchanger is the most suitable resin for uranium when it is mainly as anionic complexes. Anion exchange resins have been successfully employed to recover uranium in mining industry, especially from leach liquor (Zhang and Clifford 1994; Song et al. 1999; Huikuri and Salonen 2000; Chellam and Clifford 2002). The recovery of uranium from industrial effluents by resins and the influence of carbonate, fluoride and ammonium were studied on the uranium uptake and concluded that the uranium concentration in solution relative to other ions was the main 
factor which interfered in the separation process (Nascimentoa et al. 2004; Ladeira and Morais 2005).

The discovery of nanoporous materials (Beck et al. 1992; Feng et al. 1997; Liu et al. 1998) with large surface area and uniform pores, wide opened a new approach for the removal/entrapment of persistent inorganic pollutants (Shin et al. 1999; Jal et al. 2004; Li et al. 2007; Mangrulkar et al. 2008; Benhamou et al. 2009; Idris et al. 2011). MCM41 (Mobile Crystalline Material) is a nanoporous silicate featuring hexagonally packed arrays of one-dimensional cylindrical pores with a uniform pore distribution, large specific surface area and large pore volume (Beck et al. 1992)

In this paper, sorption behavior of uranium on nanoporous MCM-41 in the presence of some anions such as sulfate, fluoride, chloride, nitrate and phosphate was studied. The effect of contact time, $\mathrm{pH}$, initial concentration and interference of anions was investigated. This research was carried out in the 2011 for uranium recovery from the uranium conversion facility (UCF, Esfahan), Iran.

\section{Materials and methods}

Reagents

All the chemicals used were of analytical grade from Merck, except cetyltrimethylammonium bromide (CTAB) which was supplied by Aldrich (UK).

\section{Apparatus}

A Philips X'pert powder diffractometer system with $\mathrm{Cu}$ $\mathrm{K} \alpha(\lambda=1.541 \AA)$ radiation was used for X-ray studies. XRD analysis was performed from $1.5^{\circ}(2 \theta)$ to $10.0^{\circ}$ $(2 \theta)$ at a scan rate of $0.02^{\circ}(2 \theta) \mathrm{s}^{-1}$. Nitrogen sorption studies were made with a Quantachrome NOVA 2200e instrument. Nitrogen sorption and desorption isotherms of the adsorbent were determined at $77 \mathrm{~K}$ and specific surface area was determined by applying the BET equation to the isotherm (Brunauer et al. 1938). The pore size distribution was calculated using the sorption branch of the isotherm and the Barrett-Joyner-Halenda (BJH) formula (Barrett et al. 1951). The scanning electron micrographic image was recorded using a Philips microscope. TEM image was taken by JEM1200 EX with $100 \mathrm{kV}$ acceleration voltages. $\mathrm{pH}$ measurements were made with a Schott CG841 pH-meter (Germany). Quantitative determination of inorganic ions was made using an inductively coupled plasma-optical emission spectrometer (ICP-OES) of Varian Liberty 150-Axial.
Anions, such as $\mathrm{F}^{-}, \mathrm{Cl}^{-}, \mathrm{NO}_{3}{ }^{-}, \mathrm{SO}_{4}{ }^{2-}$ and $\mathrm{PO}_{4}{ }^{3-}$ in waste water were determined by ion-chromatography of Metrohm model 733. A waterbath shaker model $\mathrm{CH}_{-}$ 4311 (Infors AG) was used in the determination of distribution coefficients.

\section{Preparation of nanoporous silicate MCM-41}

The nanoporous MCM-41 was prepared by mixing sodium silicate as silicon source, and CTAB as surfactant under non-thermal condition (Sepehrian et al. 2010). In a typical procedure, $0.6 \mathrm{~g}$ CTAB was dissolved in $23 \mathrm{~g}$ of demineralized water, then, $3 \mathrm{~g}$ of sodium silicate was added and it was stirred for $30 \mathrm{~min}$. The $\mathrm{pH}$ value was adjusted at 9 by adding sulfuric acid (2 M). The stirring was continued for $4 \mathrm{~h}$. A bulky white gelatinous precipitate was formed. The resulting gel was transferred to a Teflon vessel and was left for $24 \mathrm{~h}$ at room temperature. Then the product was filtered, washed thoroughly with demineralized water and then dried at $50{ }^{\circ} \mathrm{C}$ for $12 \mathrm{~h}$. Finally, for removing surfactant, this material was calcined at $540{ }^{\circ} \mathrm{C}$ for $6 \mathrm{~h}$.

\section{Procedure for sorption studies}

Sorption studies of the uranium ion on the MCM-41 adsorbents were carried out using batch method. In this procedure, $20 \mathrm{mg}$ of adsorbent material was added to a $10 \mathrm{~mL}$ buffered solution of $2-125 \mathrm{mg} / \mathrm{L}$ uranium ions. The $\mathrm{pH}$ of the solution was adjusted with sodium hydroxide and hydrochloric acid. The suspension was stirred for a preselected period of time using a water shaker bath. Then it was filtered and the amount of uranium ion was determined by ICP. The sorption rate $(\%)$ and the sorption concentration $(q, \mathrm{~mol} / \mathrm{g})$ were calculated using the relationships:

Sorption rate $(\%)=\frac{\left(C_{\mathrm{i}}-C_{\mathrm{f}}\right)}{C_{\mathrm{i}}} \times 100$

$q(\mathrm{~mol} / \mathrm{g})=\left(C_{\mathrm{i}}-C_{\mathrm{f}}\right) \times \frac{V}{m}$

where $m$ is mass of adsorbent, $V$ the volume of uranium aqueous solution contacted with adsorbent $(\mathrm{mL}), C_{\mathrm{i}}$ the initial concentration of uranium and $C_{\mathrm{f}}$ the equilibrium concentration of uranium $(\mathrm{mg} / \mathrm{L})$ after sorption.

\section{Effect of anions}

The effect of anions on the uranium sorption was investigated at a constant concentration of uranium. In batch 


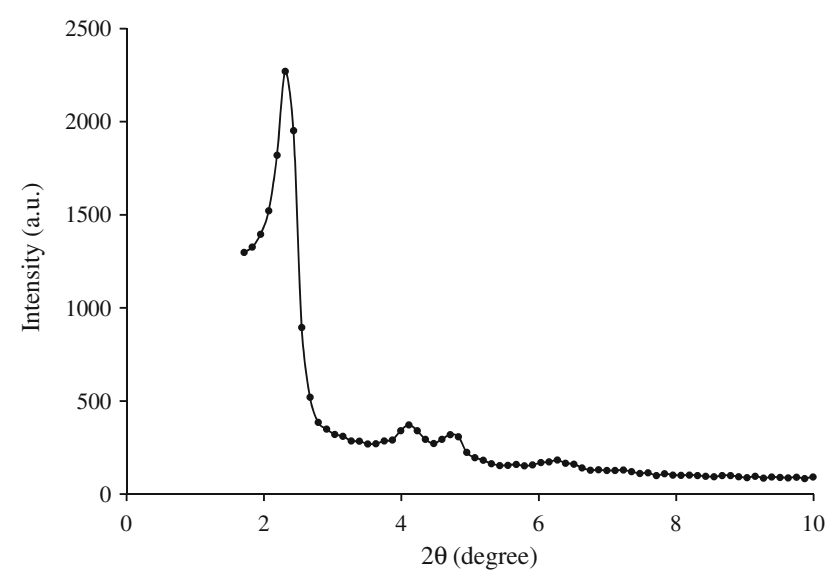

Fig. 1 XRD pattern of the nanoporous MCM-41

experiments, $20 \mathrm{mg}$ of MCM-41 adsorbent was equilibrated with $10 \mathrm{~mL}$ of the solution containing $5 \mathrm{mg} / \mathrm{L}$ of uranium ions with various concentrations of the anions [sulfate $(500-3,000 \mathrm{mg} / \mathrm{L})$, fluoride $(250-5,000 \mathrm{mg} / \mathrm{L})$, chloride $\quad(50-2,500 \mathrm{mg} / \mathrm{L})$, nitrate $\quad(10-10,000 \mathrm{mg} / \mathrm{L})$ and phosphate (10-300 mg/L)]. For competition experiments of anions, the effect of fluoride ions on the uranium sorption was also studied in the presence of other anions.

\section{Results and discussion}

\section{Characterization of adsorbent}

\section{XRD analysis}

The XRD pattern of the calcined MCM-41 is presented in Fig. 1. The XRD pattern shows a strong diffraction at $2 \theta$ smaller than $3^{\circ}$ along with the presence of small peaks that confirms the formation of nanoporous MCM-41 (Beck et al. 1992). This result is characteristic of hexagonal pore structure.

\section{Nitrogen sorption-desorption studies}

The nitrogen sorption-desorption isotherm and corresponding pore size distribution of the MCM- 41 are given in Fig. 2. $\mathrm{N}_{2}$ sorption-desorption isotherm showed a typical IV-type sorption profile consisting of a condensation due to the formation of nanopores (Fig. 2). Table 1 shows the specific surface area, pore volume and pore size of the nanoporous MCM-41.
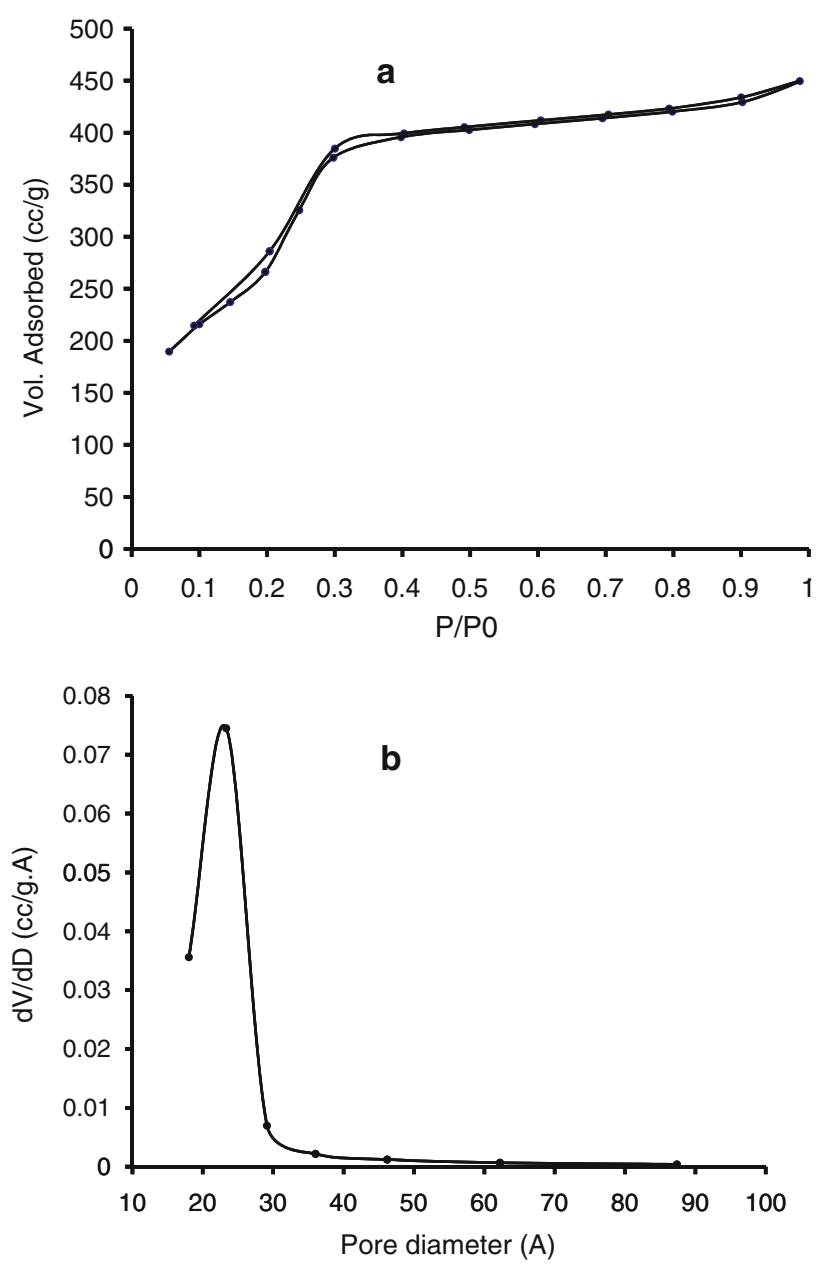

Fig. 2 a Nitrogen sorption-desorption isotherm and b pore size distribution of the nanoporous MCM-41

Table 1 Physical characteristics of the nanoporous MCM-41

\begin{tabular}{llllll}
\hline Adsorbent & $\begin{array}{l}\text { XRD } \\
d_{100} \\
(\AA)\end{array}$ & $\begin{array}{l}\text { Unit cell }_{\text {parameter }^{\mathrm{b}}} \\
\left(a_{\mathrm{o}}\right)(\AA)\end{array}$ & $\begin{array}{l}\text { Pore } \\
\text { volume } \\
(\mathrm{cc} / \mathrm{g})\end{array}$ & $\begin{array}{l}\text { BET } \\
\text { surface } \\
\text { area } \\
\left(\mathrm{m}^{2} / \mathrm{g}\right)\end{array}$ & $\begin{array}{l}\text { pore } \\
\text { diameter } \\
(\AA)\end{array}$ \\
\hline MCM-41 & 31.9 & 36.8 & 0.89 & 1,395 & 21.3 \\
\hline
\end{tabular}

${ }^{a}$ Calculated from the equation $a_{\mathrm{o}}=2 d_{100} / \sqrt{3}$

\section{Scanning electron micrograph}

The SEM image of the nanoporous MCM-41 is given in Fig. 3. The SEM image exhibit uniform spherical crystallites. 


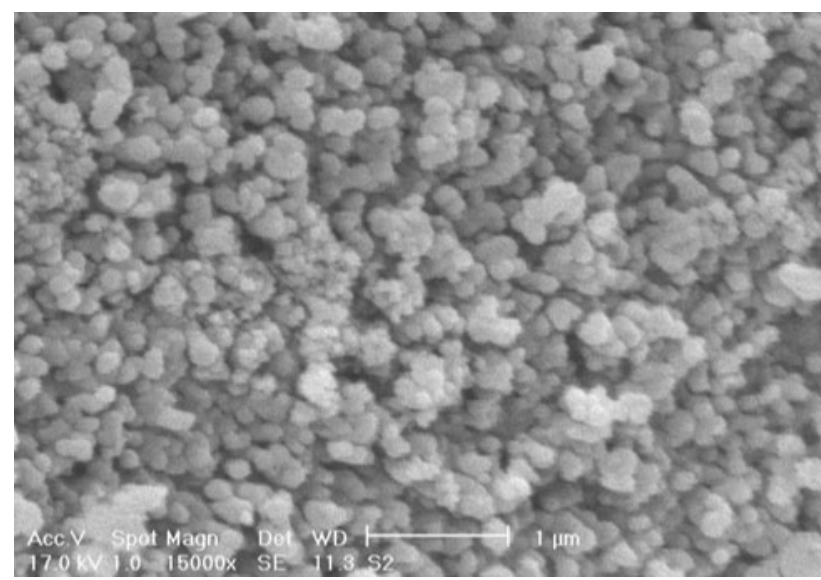

Fig. 3 Scanning electron micrograph of the nanoporous MCM-41

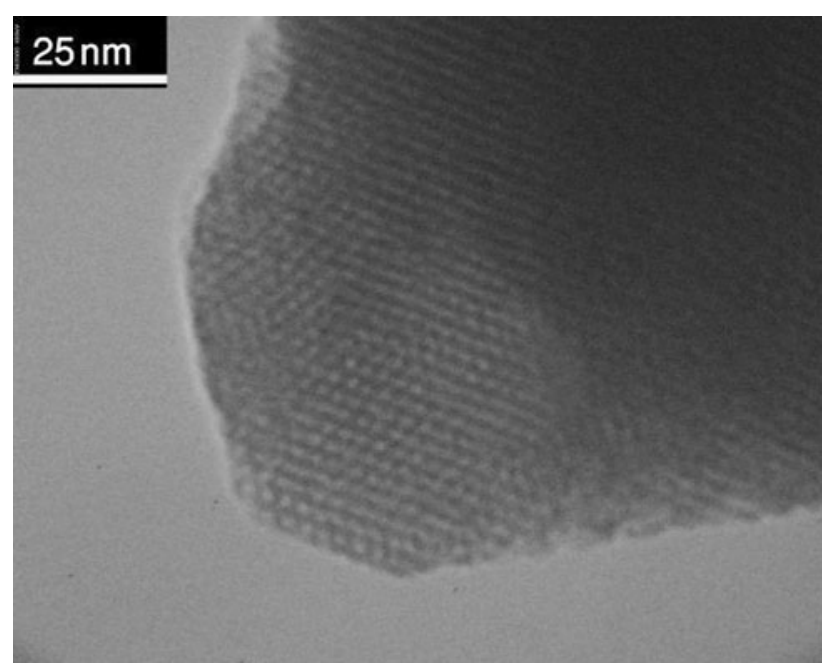

Fig. 4 Transmission electron micrograph of the nanoporous MCM-41

\section{Transmission electron micrograph}

The transmission electron micrograph of the nanoporous MCM-41 is given in Fig. 4. The TEM image shows that the pore diameter of the channels calculated from $\mathrm{N}_{2}$ sorption measurement of the nanoporous MCM-41 is about $20 \AA$.

\section{Adsorption studies}

Table 2 shows chemical analysis of UCF waste water. On basis of this result next experiments have been designed.
Table 2 Results of chemical analysis of UCF waste water

\begin{tabular}{ll}
\hline Compound & Concentration $(\mathrm{ppm})$ \\
\hline $\mathrm{U}$ & $3 \pm 0.2$ \\
$\mathrm{Si}$ & 53.4 \\
$\mathrm{Fe}$ & 1.4 \\
$\mathrm{Na}$ & 6,446 \\
$\mathrm{Ca}$ & 1.9 \\
$\mathrm{Cl}^{-}$ & 2,527 \\
$\mathrm{~F}^{-}$ & 4,842 \\
$\mathrm{NO}_{3}{ }^{-}$ & 9,920 \\
$\mathrm{SO}_{4}{ }^{2-}$ & 2,654 \\
$\mathrm{PO}_{4}{ }^{3-}$ & 248 \\
$\mathrm{pH}^{-}$ & 6.5 \\
\hline
\end{tabular}

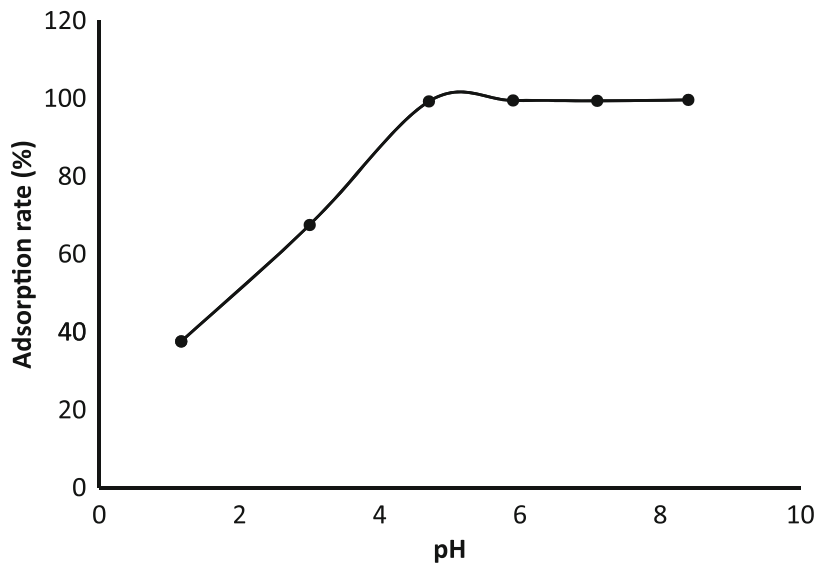

Fig. 5 Effect of $\mathrm{pH}$ on sorption of uranium onto the nanoporous MCM-41 (temperature $=25{ }^{\circ} \mathrm{C}, \quad \mathrm{C}_{0}=5 \mathrm{mg} / \mathrm{L}$ and contact time $=2 \mathrm{~h}$ )

\section{Effect of $p H$}

In general, the sorption of uranyl ions on oxides is viewed as an ion exchange reaction between the surface hydroxyl groups $(\mathrm{Si}-\mathrm{OH})$ and the uranyl ions $\left(\mathrm{UO}_{2}{ }^{2+}\right)$ or its hydrolysis products (His and Langmuir 1985; Lieser et al. 1992; Schmeide et al. 2000). The sorption of uranium was studied in the $\mathrm{pH}$ range of 1-8.

As seen in Fig. 5, the sorption of uranium varied significantly with the $\mathrm{pH}$ of solution. When $\mathrm{pH} \leq 2.0, \mathrm{UO}_{2}{ }^{2+}$ as a main cation species existed in an acidic solution. In this acidic region, silanol groups onto pores of MCM-41 were as $\mathrm{SiOH}_{2}{ }^{+}$. So, in $\mathrm{pH} \leq 2.0$, it was found that $\mathrm{U}(\mathrm{VI})$ showed no sorption towards MCM-41. After $\mathrm{pH} \geq 2$ with an increase in basicity of the aqueous solution, $\mathrm{Si}-\mathrm{OH}_{2}{ }^{+}$as a cation gradually converted to a natural $\mathrm{Si}-\mathrm{OH}$ by reacting 


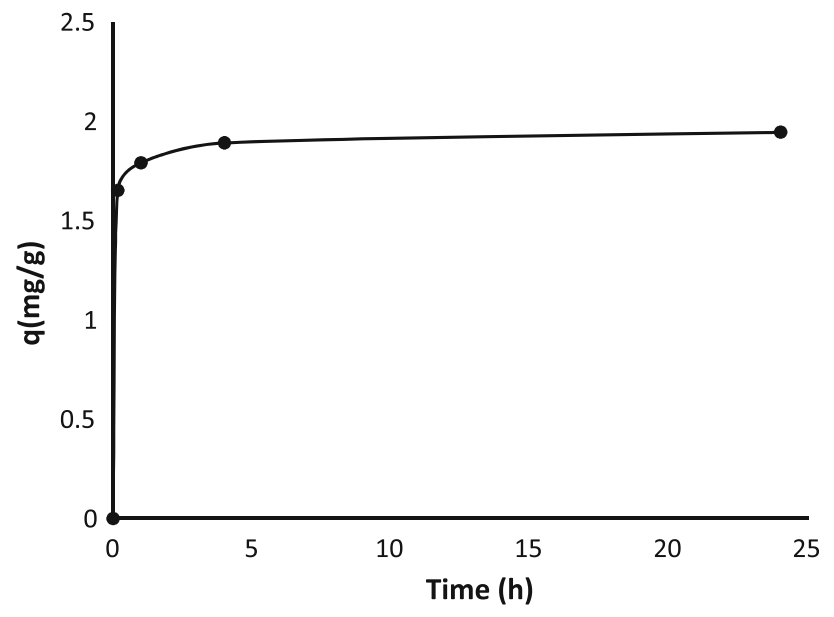

Fig. 6 Effect of contact time on sorption of uranium onto the nanoporous MCM-41 (temperature $=25^{\circ} \mathrm{C}, \quad \mathrm{pH}=6.5$ and $\left.\mathrm{C}_{0}=5 \mathrm{mg} / \mathrm{L}\right)$

with $\mathrm{OH}^{-}$, while $\mathrm{UO}_{2}{ }^{2+}$ gradually hydrolyzed to $\mathrm{UO}_{2}(\mathrm{OH})^{+}$by connecting with $\mathrm{OH}^{-}$. Since $\mathrm{UO}_{2}(\mathrm{OH})^{+}$ was a complexible species with the neutral $\mathrm{Si}-\mathrm{OH}$, so, U(VI) showed sorption towards MCM-41 adsorbent with an increase in $\mathrm{pH}$ value. The next experiments in this study were carried out at natural $\mathrm{pH}(6.5)$.

\section{Kinetic study}

The sorption kinetics experiments were carried out at an initial uranium concentration of $5 \mathrm{mg} / \mathrm{L}$ at natural $\mathrm{pH}$. As shown in Fig. 6 almost $90 \%$ uranium is adsorbed after 10 min which is efficient time when comparing with other adsorbents (Hongxia and Zuyi 2002; Hongxia et al. 2005). The fast sorption rate suggests that the silanol groups are readily available and easily accessible probably because the uniform nanoporous channels of the MCM-41 adsorbent facilitate the uranium ions transportation in the process.

\section{Sorption isotherms}

The linear sorption isotherms are plotted in Fig. 7. Among various binding models, Langmuir and Freundlich isotherms have been frequently employed to describe experimental data of sorption isotherms. The Langmuir sorption isotherm is mathematically expressed as:

$q_{\mathrm{e}}=\frac{K_{\mathrm{l}}\left(q_{\mathrm{max}}\right) C_{\mathrm{e}}}{1+K_{1} C_{\mathrm{e}}}$

where $q_{\mathrm{e}}(\mu \mathrm{mol} / \mathrm{g})$ is the amount of analyte bound to adsorbent, $C_{\mathrm{e}}(\mu \mathrm{M})$ the equilibrium concentration of adsorbate in solution, $q_{\max }$ the maximum sorption
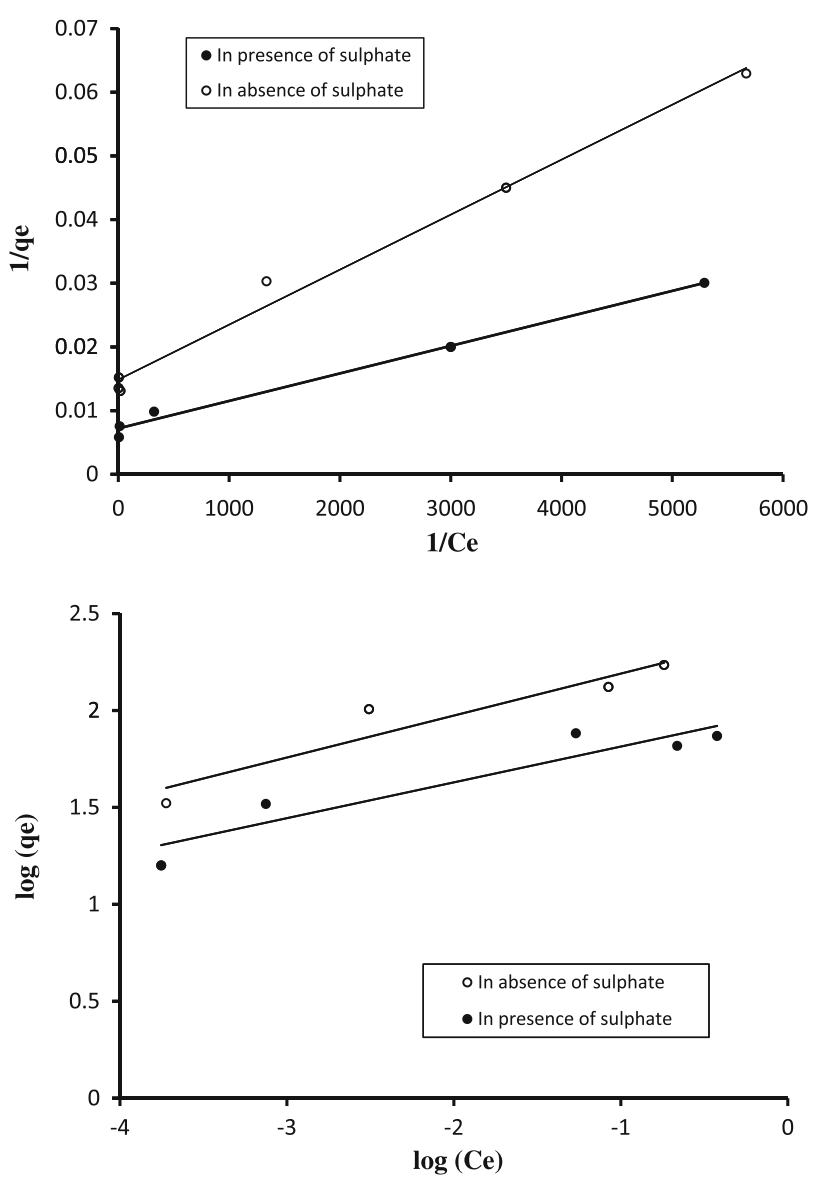

Fig. 7 Experimental sorption data (points) and Langmuir and Freundlich isotherms fit for the nanoporous MCM-41 (lines)

Table 3 Isotherm parameters obtained by using linear method

\begin{tabular}{|c|c|c|c|c|c|c|}
\hline \multirow[t]{3}{*}{ Condition } & \multicolumn{6}{|c|}{ Fitting parameters } \\
\hline & \multicolumn{3}{|c|}{ Langmuir } & \multicolumn{3}{|c|}{ Freundlich } \\
\hline & $R^{2}$ & $\begin{array}{l}K_{1} \\
(\mathrm{~L} / \mu \mathrm{mol})\end{array}$ & $\begin{array}{l}q_{\max } \\
(\mathrm{mg} / \mathrm{g})\end{array}$ & $R^{2}$ & $\begin{array}{l}K_{\mathrm{f}}(\mu \mathrm{mol} / \\
\mathrm{g} / \mathrm{mM})\end{array}$ & $m$ \\
\hline $\begin{array}{l}\text { In the presence } \\
\text { of sulfate }\end{array}$ & 0.99 & $1,245.24$ & 18.08 & 0.88 & 99.77 & 0.18 \\
\hline $\begin{array}{l}\text { In the absence } \\
\text { of sulfate }\end{array}$ & 0.99 & 801.24 & 36.02 & 0.90 & 257.04 & 0.22 \\
\hline
\end{tabular}

capacity $(\mu \mathrm{mol} / \mathrm{g})$ and $K_{1}$ the constant for a given adsorbate and adsorbent at a particular temperature. Langmuir equation is the most common model employed to describe the sorption process in homogenous systems. The equation constant values $q_{\max }$ and $\mathrm{K}_{1}$ are calculated from the experimental data (Table 3). For comparative purposes the experimental data have been fitted to the wellknown Freundlich equation. 
$q_{\mathrm{e}}=K_{\mathrm{f}} C_{\mathrm{e}}^{m}$

$K_{\mathrm{f}}$ and $m$ are constants for a given adsorbate and adsorbent at a particular temperature. From the values of $R^{2}$ summarized in Table 3 , it may be calculated that both equations fit reasonably well with the experimental data, although the Langmuir equation provides a better fiting than the Freundlich one.

\section{Effect of anions presence}

Effects of nitrate $\left(\mathrm{NO}_{3}{ }^{-}\right)$, chloride $\left(\mathrm{Cl}^{-}\right)$, fluoride $\left(\mathrm{F}^{-}\right)$, sulfate $\left(\mathrm{SO}_{4}{ }^{2-}\right)$ and phosphate $\left(\mathrm{PO}_{4}{ }^{3-}\right)$ on uranium sorption onto the nanoporous MCM-41 were evaluated (Fig. 8). The results showed that the presence of high concentration of the nitrate, chloride, sulfate and phosphate anions had no interference for uranium sorption. But the percent of uranium sorption was decreased in the presence of fluoride by about $55 \%$.

This maybe due to uranium existing as $\mathrm{UO}_{2} \mathrm{~F}_{\mathrm{n}}^{(2-\mathrm{n})+}$ complexes (Kirishima et al. 2004) in the presence of fluoride ions and it has no strange interaction with silanol groups in pores of nanoporous MCM-41. The results of uranium sorption in binary mixture of anions also showed that the fluoride interference has been decreased in the presence of phosphate anions (Fig. 9). This maybe due to the fact that the affinity complexation of uranium with phosphate is more than the fluoride ions and in the presence of phosphate, uranium is more as $\mathrm{UO}_{2}\left(\mathrm{PO}_{4}\right)_{3}{ }^{4-}$ complex and fluoride is as free ions $(\mathrm{F})$. The $\mathrm{UO}_{2}\left(\mathrm{PO}_{4}\right)_{3}{ }^{4-}$ complexes have strong interaction with silanol groups in the pores of nanoporous MCM-41. It shows that uranium can be adsorbed on the nanoporous MCM-41 in the presence of phosphate anions in UCF waste waters in the

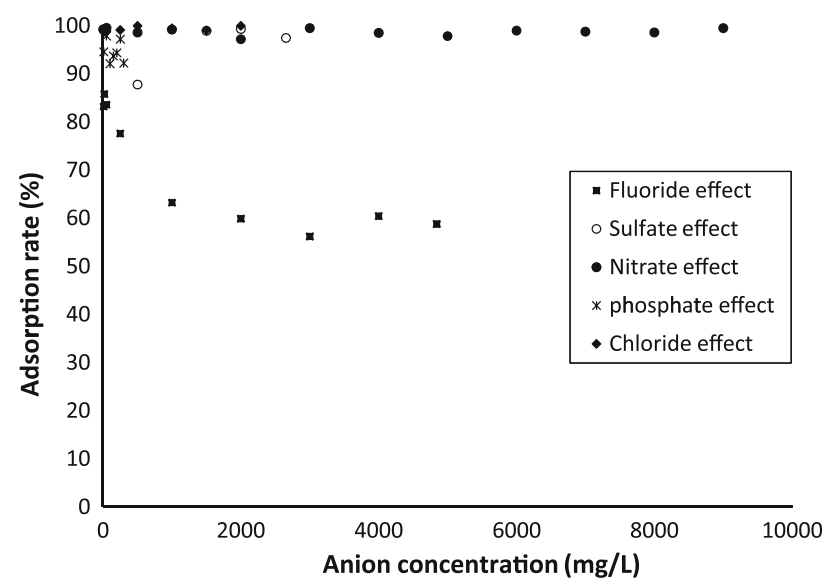

Fig. 8 Effect of anions concentration on uranium sorption [sulfate (500-3,000 mg/L), fluoride (250-5,000 mg/L), chloride (50-2,500 mg/ $\mathrm{L})$, nitrate $(10-10,000 \mathrm{mg} / \mathrm{L})$ and phosphate $(10-300 \mathrm{mg} / \mathrm{L})]$

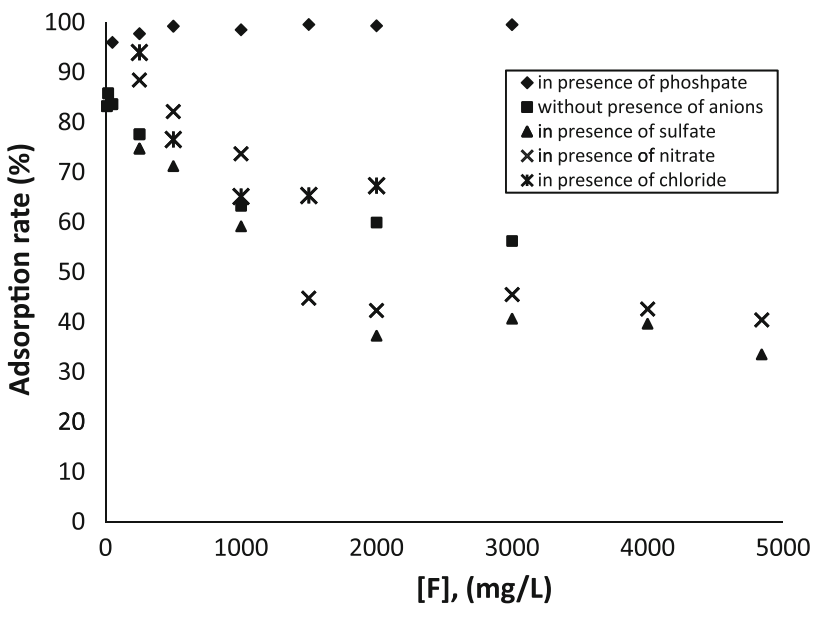

Fig. 9 Effect of fluoride in the presence of various concentration of other anions on uranium sorption [sulfate $(3,000 \mathrm{mg} / \mathrm{L})$, chloride $(2,500 \mathrm{mg} / \mathrm{L})$, nitrate $(10,000 \mathrm{mg} / \mathrm{L})$, phosphate $(300 \mathrm{mg} / \mathrm{L})$ and fluoride $(250-5,000 \mathrm{mg} / \mathrm{L})]$

Table 4 Recovery data with various eluents

\begin{tabular}{lll}
\hline Eluents & $\begin{array}{l}\text { Concentration } \\
(\mathrm{mol} / \mathrm{L})\end{array}$ & $\begin{array}{l}\text { Recovery } \\
(\%)\end{array}$ \\
\hline $\mathrm{HCl}$ & 0.1 & 93 \\
& 0.5 & 73 \\
& 1.5 & 65 \\
$\mathrm{H}_{2} \mathrm{SO}_{4}$ & 0.1 & 72 \\
& 0.5 & 68 \\
& 2 & 58 \\
$\mathrm{HNO}_{3}$ & 0.1 & 70 \\
& 0.5 & 70 \\
& 2 & 65 \\
\hline
\end{tabular}

presence of other anions and/or adding phosphate anions to UCF waste waters can decrease interference of other anions.

\section{Uranium recovery}

Desorption behavior was also studied after washing the column with acid solution such as nitric acid, sulfuric acid and hydrochloric acid in various concentrations (Table 4). The results show that the highest recovery (93\%) was obtained with $0.1 \mathrm{~mol} / \mathrm{L} \mathrm{HCl}$ solution.

\section{Conclusion}

Nanoporous MCM-41 was used for uranium recovery and showed high capacity for uranium $(36.02 \mathrm{mg} / \mathrm{g}$ in 
the absence of anions and $18.08 \mathrm{mg} / \mathrm{g}$ in the presence of sulfate anion). The results obtained by batch experiments showed that the presence of high concentration of nitrate, sulfate, chloride and phosphate anions alone had no interference for uranium recovery. The result also shows that uranium can be adsorbed on the nanoporous MCM-41 in the presence of phosphate anions, in the presence of other anions and/or adding phosphate anions to waste waters can decrease the interference of other anions.

Acknowledgments The authors gratefully acknowledge the support of this work by analysis section, NFCRS, Nuclear Science and Technology Research Institute.

\section{References}

Akhtar K, Khalid AM, Akhtar MW, Ghauri MA (2009) Removal and recovery of uranium from aqueous solutions by $\mathrm{Ca}$-alginate immobilized Trichoderma harzianum. Bioresour Technol 100:4551-4558

Amamoto I, Terai T, Oobayashi H, Fujit R (2005) Separation and recovery study of uranium from spent $\mathrm{NaF}$ (fillers). J Phys Chem Solids 66:602-607

Barrett EP, Joyner LG, Halenda PP (1951) The determination of pore volume and area distributions in porous substances. I. computations from nitrogen isotherms. J Am Chem Soc 73:373-380

Beck JS, Vartuli JC, Roth WJ, Leonowics ME, Kresge CT, Schmitt KD, Chu CTW, Olson DH, Sheppard EW, Mccullen SB, Higgins JB, Schlenker JL (1992) A new family of mesoporos molecular sieves prepared with liquid crystal templates. J Am Chem Soc 114:10834-10843

Benhamou A, Baudu M, Derriche Z, Basly JP (2009) Aqueous heavy metals removal on amine-functionalized Si-MCM-41 and Si-MCM-48. J Hazard Mater 171:1001-1008

Brunauer S, Emmett PH, Teller E (1938) Adsorption of gases in multimolecular layers. J Am Chem Soc 60:309-319

Chaudhury S, Singh Mudher KD, Venugopal V (2003) Recovery of uranium from fluoride matrix by solid state reaction routes. J Nucl Mater 322:119-125

Chellam S, Clifford DA (2002) Physical-chemical treatment of groundwater contaminated by leachate from surface disposal of uranium tailings. J Environ Eng 128:942-952

Feng X, Fryxell GE, Wang LQ, Kim AY, Liu J (1997) Functionalized monolayers on ordered mesoporous supports. Science 276:923926

His CKD, Langmuir D (1985) Adsorption of uranyl onto ferric oxyhydroxide: application of the surface site-binding model. Geochim Cosmochim Acta 49:1931-1941

Hongxia Z, Zuyi T (2002) Sorption of uranyl ions on silica: effects of contact time, $\mathrm{pH}$, ionic strength, concentration and phosphate. J Radioanal Nucl Chem 254:103-107

Hongxia Z, Yongxin X, Zuyi T (2005) Sorption of uranyl ions on gibbsite: effects of contact time, $\mathrm{pH}$, ionic strength, concentration and anion of electrolyte. Colloid Surface Physicochem Eng Aspect 252:1-5

Huikuri P, Salonen L (2000) Removal of uranium from Finnish groundwaters in domestic use with a strong base anion resin. J Radioanal Nucl Chem 245:385-393
Idris SA, Davidson CM, McManamon C, Morris MA, Anderson P, Gibson LT (2011) Large pore diameter MCM-41 and its application for lead removal from aqueous media. J Hazard Mater 185:898-904

Jal PK, Patel S, Mishra BK (2004) Chemical modification of silica surface by immobilization of functional groups for extractive concentration of metal ions. Talanta 62:1005-1102

James D, Venkateswaran G, Prasada Rao T (2009) Removal of uranium from mining industry feed simulant solutions using trapped amidoxime functionality within a mesoporous imprinted polymer material. Micropor Mesopor Mater 119: $165-170$

Kirishima A, Kimura T, Tochiyama O, Yoshida Z (2004) Speciation study on complex formation of uranium(VI) with phosphate and fluoride at high temperatures and pressures by time-resolved laser-induced fluorescence spectroscopy. Radiochim Acta 92:889-896

Kulkarni PS (2003) Recovery of uranium(VI) from acidic wastes using tri-n-octylphosphine oxide and sodium carbonate based liquid membranes. Chem Eng J 92:209-214

Ladeira ACQ, Morais CA (2005) Effect of ammonium, carbonate and fluoride concentration on the uranium recovery by resins. Radiochim Acta 93:207-209

Li J, Qi T, Wang L, Liu C, Zhang Y (2007) Synthesis and charactrization of imidazole-functionalized SBA-15 as an adsorbent of hexavalent chromium. Mater Lett 61(2007): 3197-3200

Lieser KH, Quandt-Klenk S, Thybusch B (1992) Sorption of uranyl ions on hydrous silicon dioxide. Radiochim Acta 57:45-50

Liu J, Feng X, Fryxell GE, Wang LQ, Kim AY, Gong M (1998) Hybrid mesoporous materials with functionalized monolayers. Adv Mater 10:161-165

Mangrulkar PA, Kamble SP, Meshram J, Rayalu SS (2008) Adsorption of phenol and o-chlorophenol by mesoporous MCM-41. J Hazard Mater 160:414-421

Michard P, Guibal E, Vincent T, Le Cloirec P (1996) Sorption and desorption of uranyl ions by silica gel: $\mathrm{pH}$, particle size and porosity effects. Micropor Mater 5:309-324

Mirjalili K, Roshani M (2007) Resin-in-pulp method for uranium recovery from leached pulp of low grade uranium ore. Hydrometallurgy 85:103-109

Nakajima A, Sakaguchi T (1999) Recovery of uranium from uranium refining waste water by using immobilized persimmon tannin. J Radioanal Nucl Chem 242:623-626

Nascimentoa MRL, Fatibello-Filhob O, Teixeira LA (2004) Recovery of uranium from acid mine drainage water by ion exchange. Miner Process Extr Metall Rev 25:129-142

Schmeide K, Pompe S, Bubner M, Heise KH, Bernhard G, Nitsche $\mathrm{H}$ (2000) Uranium(VI) sorption onto phyllite and selected minerals in the presence of humic acid. Radiochim Acta $88: 723-728$

Sepehrian H, Ahmadi SJ, Waqif-Husain S, Faghihian H, Alighanbari $\mathrm{H}$ (2010) Adsorption studies of heavy metal ions on mesoporous aluminosilicate, novel cation exchanger. J Hazard Mater 176:252-256

Shin YS, Burleigh MC, Dai S, Barnes CE, Xue ZL (1999) Investigation of uranyl sorption on mesoporous titanium-based sorbents. Radiochim Acta 84:37-42

Singh SK, Dhami PS, Tripathi SC, Dakshinamoorthy A (2009) Studies on the recovery of uranium from phosphoric acid medium using synergistic mixture of (2-Ethyl hexyl) Phosphonic acid, mono (2-ethyl hexyl) ester (PC88A) and Tri- $n$-butyl phosphate (TBP). Hydrometallurgy 95:170-174

Song Y, Wang Y, Wang L, Song C, Yang ZZ, Zhao A (1999) Recovery of uranium from carbonate solutions using strongly 
basic anion exchanger 4: column operation and quantitative analysis. React Funct Polym 39:245-252

Tsuruta T (2002) Removal and recovery of uranyl ion using various microorganisms. J Biosci Bioeng 94:23-28
Zhang Z, Clifford DA (1994) Exhausting and regenerating resin for uranium removal. J Am Water Works Assoc 86:228-241 